\title{
Mitochondrial DNA and Y-chromosomal diversity in ancient populations of domestic sheep (Ovis aries) in Finland: comparison with contemporary sheep breeds
}

Marianna Niemi ${ }^{1}$, Auli Bläuer ${ }^{1,2}$, Terhi Iso-Touru' ${ }^{1}$, Veronica Nyström³, ${ }^{3,5 a n n e ~ H a r j u l a 1,2, ~ J u s s i-P e k k a ~ T a a v i t s a i n e n ², ~}$ Jan Storå ${ }^{4}$, Kerstin Lidén ${ }^{4}$ and Juha Kantanen ${ }^{1 *}$

\begin{abstract}
Background: Several molecular and population genetic studies have focused on the native sheep breeds of Finland. In this work, we investigated their ancestral sheep populations from Iron Age, Medieval and Post-Medieval periods by sequencing a partial mitochondrial DNA D-loop and the 5'-promoter region of the SRY gene. We compared the maternal (mitochondrial DNA haplotypes) and paternal (SNP oY1) genetic diversity of ancient sheep in Finland with modern domestic sheep populations in Europe and Asia to study temporal changes in genetic variation and affinities between ancient and modern populations.

Results: A 523-bp mitochondrial DNA sequence was successfully amplified for 26 of 36 sheep ancient samples i.e. five, seven and 14 samples representative of Iron Age, Medieval and Post-Medieval sheep, respectively. Genetic diversity was analyzed within the cohorts. This ancient dataset was compared with present-day data consisting of 94 animals from 10 contemporary European breeds and with GenBank DNA sequence data to carry out a haplotype sharing analysis. Among the 18 ancient mitochondrial DNA haplotypes identified, 14 were present in the modern breeds. Ancient haplotypes were assigned to the highly divergent ovine haplogroups A and B, haplogroup $B$ being the major lineage within the cohorts. Only two haplotypes were detected in the Iron Age samples, while the genetic diversity of the Medieval and Post-Medieval cohorts was higher. For three of the ancient DNA samples, Y-chromosome SRY gene sequences were amplified indicating that they originated from rams. The SRY gene of these three ancient ram samples contained SNP G-oY1, which is frequent in modern north-European sheep breeds.

Conclusions: Our study did not reveal any sign of major population replacement of native sheep in Finland since the Iron Age. Variations in the availability of archaeological remains may explain differences in genetic diversity estimates and patterns within the cohorts rather than demographic events that occurred in the past. Our ancient DNA results fit well with the genetic context of domestic sheep as determined by analyses of modern north-European sheep breeds.
\end{abstract}

\footnotetext{
* Correspondence: juha.kantanen@mtt.fi

${ }^{1}$ Biotechnology and Food Research, MTT Agrifood Research Finland, Fl-31600, Jokioinen, Finland

Full list of author information is available at the end of the article
} 


\section{Background}

Archaeological and molecular genetic evidence suggests that sheep's (Ovis aries) wild ancestor was the Asiatic mouflon (O. orientalis) and that it was domesticated about 11000 years ago in the Fertile Crescent region [1]. The genetic history of the domestication of sheep has been investigated by analysing maternally inherited mitochondrial DNA (mtDNA) in modern sheep breeds. To date, five phylogenetically divergent mtDNA haplogroups descending probably from several O. orientalis populations have been identified in domestic sheep [2] i.e. haplogroups $A$ and $B$ that are present in sheep in many parts of the world and haplogroups $C, D$ and $E$ that have a much more restricted geographic range $[2,3]$. Sheep spread across Europe in separate migration episodes over time from their domestication site in the Near East [4]. Chessa et al. [4] have provided evidence that contemporary sheep breeds and populations of north-western and northern Europe, e.g. the Finnish native sheep breeds, Finnsheep, Kainuu Grey and Aland still share genetic ancestry with the most primitive type of sheep in Europe descending from the first immigrant wave [4].

The earliest archeological record for burned sheep bone in Finland dated by radiocarbon is from the late Stone Age (3 679 \pm 33 BP, cal 2150-1950 BC; [5]). However, such archaeological evidence of animal husbandry in Finland is scarce and domesticated animals may have arrived in Finland with the expansion of the Corded Ware culture from the south via the Baltics, but also from the west (Scandinavia) and east (Russia). Available archaeological data indicate that, in Finland, sheep husbandry developed first in fairly limited areas of the southern and south-western regions. The size of the sheep population was then probably quite small and the arrival of any new animals e.g. with immigrants would have had a significant effect on the population's gene pool. During the Iron Age, agriculture developed in eastern and central Finland until reaching the northern limit of permanent cultivation (ca. $62^{\circ} \mathrm{N}$ latitude) [6].

Population size, demography and morphological characters of medieval sheep in Finland can be inferred from historical tax registers. For example, in 1620, there were at least 188300 sheep in Finland [7]. Foreign "Spanish" sheep (i.e. ancestors of modern Merino sheep) with finer wool were imported into Finland at least from the 16th century onwards to serve the local wool industry [8]. Exotic breeding material was introduced mainly through imported rams, which means that the admixture may not have shaped the original mtDNA diversity in the Finnish native sheep. However, nuclear marker analysis of modern sheep breeds has shown that imported animals probably had a limited effect on the gene pool of the Finnish sheep population [9]. The Finnish Sheep Breeding Organization was established in 1918 and breeding of the main native breed, Finnsheep, depended essentially on animals from the eastern part of Finland [10].

In recent years, several molecular and population genetic studies have focused on the modern Finnish native sheep breeds with analyses of within-population diversity and population structure using mtDNA, Y-chromosome markers, autosomal microsatellites and whole-genome SNP $[3,9,11-15]$. It has been shown that the three native Finnish sheep breeds, Finnsheep, Kainuu Grey and Alland and several other North-European native sheep breeds belong to the Nordic group of short tailed sheep $[13,14]$. Two different mtDNA haplogroups, A and B, segregate in the Finnish native sheep and as in other European sheep breeds; haplogroup B is much more frequent than haplogroup A [3]. In addition, Meadows et al. [12] reported that the three different Y-chromosome haplotypes assigned to two different haplogroups were present in Finnsheep, Kainuu Grey and Åland breeds.

In this study, we present a new approach to the molecular and population genetics of the Finnish native sheep breeds based on the analysis of ancient DNA (aDNA) from ancestral populations from the Late Iron Age (800-1200 AD), Medieval (1200-1550 AD) and Post-Medieval periods (1550-1800 AD). Comparing the genetic diversity of ancient populations with contemporary breeds can reveal temporal genetic changes and gene pool developments, as exemplified in a cattle Ychromosome study [16] and in a mtDNA analysis for inferring the domestication history of European pigs [17]. However, ancient DNA studies can also reveal relatively minor changes in population diversity patterns. For example, frequencies of the mtDNA haplogroups $\mathrm{A}$ and $B$ detected in ancient Chinese sheep populations from the Bronze Age are similar to those in contemporary Chinese sheep breeds $[18,19]$.

We investigated the genetic diversity of ancient sheep remains in Finland by sequencing a 523-bp mtDNA Dloop sequence and a 130-bp segment in the 5'-promoter region of the ovine sex determining region $Y(S R Y)$ gene to detect a biallelic Y-chromosome SNP marker $o Y 1$. We compared mtDNA and Y-chromosome marker data from ancient and modern domestic sheep populations in Finland and other parts of Europe and Asia and studied temporal changes in maternal and paternal genetic diversity and mtDNA diversity patterns. For the mtDNA study, two modern datasets were used: (1) 10 modern European sheep breeds were sequenced and (2) additional mtDNA sequences were collected from GenBank that spanned the same mtDNA D-loop nucleotide sites as those present in the ancient mtDNA sequences. To our knowledge, this is the first time that mtDNA and Ychromosome genetic diversities of ancient sheep populations are investigated in the same study. 


\section{Materials and methods}

\section{Ancient sheep bone material}

For the aDNA analysis, 36 sheep bones were selected from 14 different locations and 18 different archaeological excavations across Finland and one site in northern Norway (Table 1, Additional file 1: Figure S1). As a rule, unburned bone from time periods prior to the Late Iron Age is not preserved in the Finnish acid soil; thus earlier bone material consists of small burned fragments that are not useful for aDNA analyses [20]. The earliest unburned bones available for this study derive from the Late Iron Age (800-1200 AD).

When possible, metacarpal or metatarsal bones were selected for two reasons: (1) these bones are easy to distinguish between sheep and goats and (2) they are often found in a complete or semi-complete state in the excavations because since they are nutritionally poor they were not usually butchered for cooking. However, other bone elements were also sampled, e.g. when metapodials were not present in the sample, or were badly preserved or fragmented, or if they did not form the highest Minimum Number of Individuals (MNI) within the excavation or phase. In some cases, only bones that are directly identifiable as from sheep or goat (e.g. teeth) were selected because it is possible to identify a species from analyses of the mtDNA Dloop region. Care was taken not to sample the same individual twice i.e. within one site and phase, elements located on the same side were selected for a given sample, otherwise age and size of the animal were used to separate different individuals. All samples that based on the archaeological context were assumed to originate from the Iron Age or Medieval period were radiocarbon-dated. In addition, Post-Medieval samples for which dating was uncertain from the archaeological context, were also radiocarbon-dated. Nineteen sheep bones or teeth were radiocarbon-dated in the Laboratory of Chronology of the Finnish Museum of Natural History, University of Helsinki (Table 1).

\section{Iron age}

Eleven samples excavated at four different sites from the Iron Age were included in this study (Table 1, Additional file 1: Figure S1). The aDNA samples (sample ID: OaM1-5) belong to the Viking Age phase of the Mulli site (1090-930 BP, Table 1). The animal bone assemblage from this site is mainly composed of domestic animals, but also contains a variety of wild mammals. Eastern Finland Viking Age sites were sampled (OaSys1 and OaMik1) and samples from two Iron Age cemetery sites in south-west and southern Finland (OaLui1-2 and OaKir1) were collected. The sample from Brodtkorbneset, Pasvik (Norway) (OaPas1) derives from a rectangular hearth of Sami origin and also dates to the late Iron Age $(984 \pm 31$ BP, Table 1).

\section{Medieval period}

Eleven samples from western and eastern Finland from the Medieval period were analysed (Table 1, Additional file 1: Figure S1) among which eight originated from the town of Turku (OaAA3-6, OaVet1-4), the largest Medieval town in Finland that is situated on the southwest coast by the river Aura, one from Bridgettine Abbey of Naantali (OaNaa1) situated in south-west Finland ca. $18 \mathrm{~km}$ from Turku, one from Kökar monastery, a medieval Franciscan monastery situated in the Åland archipelago (OaKök1), and one from eastern Finnish Karelia i.e. a deserted Greek Orthodox village in Papinniemi in Uukuniemi (OaUuk2).

\section{Post-Medieval period}

Fourteen samples from the Post-Medieval period were analysed (Table 1, Additional file 1: Figure S1) among which six were collected from the shores of the Gulf of Bothnia, from Pietarsaari (OaPie1), Tornio (OaTor1-2) and Oulu (OaOul1-3), seven from south-west and southern Finland i.e. two from Kökar monastery (OaKök2-4), two from Turku (OaÅA1-2) and two from Helsinki (OaHel1-2), both in urban contexts and one from an inland region at Pihtipudas (OaPih1).

\section{Modern sheep}

The occurrence of ancient sheep mtDNA sequences in modern sheep breeds was investigated with two datasets: (1) our own dataset of 94 unrelated animals from 10 sheep breeds or local varieties [see Additional file 1: Figure S1] and (2) a dataset composed of GenBank sequence data of 50 European and Asian sheep breeds previously published. Our own dataset was also used for the comparison between ancient and modern DNA. Previously described in $[3,14]$, breeds included in our own dataset are the following: the Finnish native sheep breeds Finnsheep, Kainuu Grey and Åland, the Viena sheep from Russian Karelia, Bozakh sheep from the Caucasus, Romanov and Oparino sheep from central Russia, Olkuska sheep from Poland, the morphological type of Vlashko Vitoroga-Pramenka sheep from Serbia and Oxford Down sheep from the UK. All sheep breeds were locally developed breeds except for Oxford Down, which is a synthetic commercial English breed [40]. Kainuu Grey, Åland, Oparino, Olkuska and Vlashko Vitoroga-Pramenka sheep have undergone a reduction in population size during the last 10 years and are rare or endangered breeds. Results from a Y-chromosome SNP $o Y 1$ analysis in ancient sheep were compared with those of a global sheep Y-chromosome study including Finnsheep, Kainuu Grey and Åland sheep [12]. 
Table 1 Summary of ancient samples studied in this article

\begin{tabular}{|c|c|c|c|c|c|c|c|}
\hline \multicolumn{4}{|c|}{ Sample } & \multicolumn{2}{|c|}{ Dating } & \multicolumn{2}{|c|}{ aDNA } \\
\hline Sample ID & Location & Site & Bone type & ${ }^{*} \mathrm{BP}( \pm 1 \sigma)$ & **Period & mtDNA & SRY gene \\
\hline OaMik1 & Mikkeli & Moisio Latokartano [21] & Mandible & $865 \pm 33$ & Iron Age & No & \\
\hline OaM1 & Raisio & Mulli [22] & Metacarpal & $965 \pm 30$ & Iron Age & Yes & unreadable \\
\hline $\mathrm{OaM2}$ & Raisio & Mulli [22] & Metacarpal & $1040 \pm 31$ & Iron Age & Yes & No \\
\hline OaM3 & Raisio & Mulli [22] & Metacarpal & $955 \pm 30$ & Iron Age & Yes & unreadable \\
\hline OaM4 & Raisio & Mulli [22] & Metacarpal & $995 \pm 30$ & Iron Age & Yes & unreadable \\
\hline OaM5 & Raisio & Mulli [22] & Metacarpal & $1081 \pm 32$ & Iron Age & Yes & unreadable \\
\hline OaSys1 & Sysmä & Ihananiemi [23] & Tooth (Molar) & $1093 \pm 31$ & Iron Age & No & \\
\hline OaKir1 & Turku & Kirkkomäki [24] & Tooth fragments & NA & Iron Age & No & \\
\hline OaLui1 & Eura & Luistari $[25,26]$ & Tooth fragments & NA & Iron Age & No & \\
\hline OaLui2 & Eura & Luistari $[25,26]$ & Tooth fragments & NA & Iron Age & No & \\
\hline OaPas1 & Pasvik (Norway) & Brodtkorbneset [27] & Metatarsal & $984 \pm 31$ & Iron Age & Partial & No \\
\hline OaNaa1 & Naantali & Luostari [28] & Metacarpal & $452 \pm 30$ & Medieval & Yes & Yes \\
\hline OaUuk2 & Uukuniemi & Papinniemi [29] & Metatarsal & $410 \pm 30$ & Medieval & Yes & No \\
\hline OaÅA3 & Turku & Åbo Akademi [30] & Metacarpal & $506 \pm 32$ & Medieval & Yes & No \\
\hline OaÅA4 & Turku & Åbo Akademi [30] & Metacarpal & $581 \pm 31$ & Medieval & Yes & No \\
\hline OaÅA5 & Turku & Åbo Akademi [30] & Metacarpal & $722 \pm 32$ & Medieval & Yes & No \\
\hline OaÅA6 & Turku & Åbo Akademi [30] & Metacarpal & $737 \pm 32$ & Medieval & Yes & No \\
\hline OaVet1 & Turku & Aboa Vetus $[28,31]$ & Horncore & $487 \pm 30$ & Medieval & No & \\
\hline OaVet2 & Turku & Aboa Vetus $[28,31]$ & Maxilla & $\mathrm{DBC}$ & Medieval & No & \\
\hline OaVet3 & Turku & Aboa Vetus $[28,31]$ & Axis & $550 \pm 30$ & Medieval & No & \\
\hline OaVet4 & Turku & Aboa Vetus $[28,31]$ & Lower jaw & DBC & Medieval & No & \\
\hline OaKök1 & Kökar & Kloster [32] & Metacarpal & $489 \pm 30$ & Medieval & Yes & No \\
\hline OaHel1 & Helsinki & Snellmaninkatu [33] & Metatarsal & $\mathrm{DBC}$ & Post-Med & Yes & No \\
\hline OaHel2 & Helsinki & Snellmaninkatu [33] & Metatarsal & $\mathrm{DBC}$ & Post-Med & Yes & No \\
\hline OaOul1 & Oulu & Kajaaninkatu [34] & Radius & DBC & Post-Med & Yes & No \\
\hline OaOul2 & Oulu & Lyseo [35] & Radius & DBC & Post-Med & Yes & No \\
\hline OaOul3 & Oulu & Pikisaari [36] & Radius & $\mathrm{DBC}$ & Post-Med & Yes & No \\
\hline OaPie1 & Pietarsaari & Lassfolk [37] & Metacarpal & DBC & Post-Med & Yes & No \\
\hline OaTor1 & Tornio & Keskikatu [38] & Metacarpal & $\mathrm{DBC}$ & Post-Med & Yes & Yes \\
\hline OaTor2 & Tornio & Keskikatu [38] & Metacarpal & $\mathrm{DBC}$ & Post-Med & Yes & No \\
\hline OaÅA1 & Turku & Åbo Akademi [30] & Metacarpal & DBC & Post-Med & Yes & unreadable \\
\hline OaÅA2 & Turku & Åbo Akademi [30] & Metacarpal & DBC & Post-Med & Yes & No \\
\hline OaPih1 & Pihtipudas & Hämeensaari [39] & Tibia & $342 \pm 30$ & Post-Med & Yes & No \\
\hline OaKök2 & Kökar & Kloster [32] & Metacarpal & $305 \pm 30$ & Post-Med & Yes & Yes \\
\hline OaKök3 & Kökar & Kloster [32] & Metacarpal & DBC & Post-Med & Yes & No \\
\hline OaKök4 & Kökar & Kloster [32] & Metacarpal & $\mathrm{DBC}$ & Post-Med & Yes & No \\
\hline
\end{tabular}

Identity of samples include: sample ID, location i.e. town where samples were excavated, archaeological site, and type of bone (museums ID available upon request); dating of samples include radiocarbon-dates $\left({ }^{*} \mathrm{BP}( \pm 1 \sigma)\right)$ or dates estimated by the context $(\mathrm{DBC})$ and corresponding historical **periods $($ Post-Med $=$ Post-Medieval); results of mtDNA D-loop and Y-chromosomal SRY gene sequence analysis are indicated for each sample; only the samples yielding mtDNA were analysed for the $S R Y$ gene.

DNA extraction and laboratory methods Laboratory environment and DNA extraction of ancient sheep samples

Bone samples were prepared by removing the outer layer of the bones and collecting 50 to $200 \mathrm{mg}$ of bone powder with a drill. DNA extraction was carried out in an air-controlled sterile laboratory and in a laminar flow hood (EU-14 HEPA filtered air under positive air pressure isolation). Separate laboratories were used for sample preparation, DNA extraction and PCR amplification. 
The laboratories and equipment were UV-treated and bleach was used to clean the laminar and laboratory regularly. Protective whole body suits, double gloves and masks were used inside the aDNA laboratory. Two aDNA laboratories participated in aDNA analyses (MTT Agrifood Research Finland and Stockholm University, Sweden).

DNA extraction was carried out as described in [41]. The bone powder was digested in $900 \mu \mathrm{L} 0.5 \mathrm{M}$ EDTA, $100 \mu \mathrm{L} 10 \mathrm{M}$ urea and $5 \mu \mathrm{L}$ proteinase $\mathrm{K}(20 \mathrm{mg} / \mathrm{ml})$ with constant stirring at $55^{\circ} \mathrm{C}$ overnight. After centrifugation (2000 rpm for $5 \mathrm{~min}$ ), the supernatant was concentrated and DNA was extracted with a QIAquick PCR Purification Kit (Qiagen, Sweden) according to the manufacturer's instructions.

\section{DNA markers, primer design and $P C R$}

A 523-bp sequence of mtDNA encompassing part of the mtDNA D-loop from ancient sheep ([GenBank: NC001941] positions 15,978-16,501) was analysed. A 130-bp sequence in the 5'-promoter region of the SRY gene on ovine Y-chromosome ([GenBank:AY604734] positions 58-179) was analysed to detect the Ychromosome SNP marker (oY1) [GenBank:AY604734.2: g.67, A>G].

Primers [see Additional file 2: Table S1] for five overlapping fragments of mtDNA D-loop sequence and one Y-chromosome SRY gene fragment were designed with Primer3 [42] using mtDNA and SRY gene reference sequences [GenBank:NC001941] and [GenBank: AF026566.1], respectively.

PCR for ancient DNA was performed in $25 \mu \mathrm{L}$ mixture that contained $1 \times$ PCR buffer (Qiagen, Sweden), $0.2 \mu \mathrm{M}$ of each primer, $0.4 \mathrm{mM} \mathrm{dNTP}, 2.5 \mathrm{mM} \mathrm{MgCl}_{2}$ (Qiagen, Sweden), 0.25 units (U) of Uracil DNA Glycosylase (UNG, Sigma-Aldrich), 1.5 U of HotStarTaq DNA Polymerase (Qiagen, Sweden) and $5-10 \mu \mathrm{L}$ of DNA extract. The PCR program consisted in initial steps at $37^{\circ} \mathrm{C}$ for $10 \mathrm{~min}$ and $95^{\circ} \mathrm{C}$ for $15 \mathrm{~min}$ followed by 55 three-step cycles at $94^{\circ} \mathrm{C}$ for $30 \mathrm{~s}, \mathrm{AT}^{\circ} \mathrm{C}$ for $40 \mathrm{~s}$ and $72^{\circ} \mathrm{C}$ for $1 \mathrm{~min}$ and a final step at $72^{\circ} \mathrm{C}$ for $10 \mathrm{~min}$. AT stands for the annealing temperature specific to each primer set [see Additional file 2: Table S1].

\section{Authenticity of ancient sheep DNA}

Common measures to prevent contamination were used $[43,44]$, such as separated areas for sample preparation, ancient DNA analyses and pre-PCR, wearing protective clothing, using disposable tools and pipettes with aerosol resistant filter tips and treating equipment and working surfaces with bleach and ultra-violet irradiation frequently (see DNA extraction and laboratory methods). Overlapping primers specific to sheep DNA were designed to prevent possible annealing to human DNA and were checked by amplification (see DNA extraction and laboratory methods).

The authenticity of the aDNA analysis was controlled at various steps of the laboratory work-flow. In general, when consistent sequences were obtained in three or more amplifications, the sequence was considered reproducible and accepted as authentic. In the aDNA extraction step, 13 of the samples (out of the 26 samples which were successfully amplified for the 523-bp mtDNA Dloop sequence) (Table 1) were extracted several times, and at least two PCR-reactions were performed for separate DNA extractions to amplify and sequence each overlapping mtDNA D-loop fragment at least twice. Applying these strict extraction and amplification steps aimed at confirming the reproducibility of our aDNA sequence protocol and no sequence anomalies were detected. Moreover, five samples (OaM1, OaNaa1, OaTor2, OaÅA5 and OaÅA6) were extracted, amplified and sequenced in two different aDNA laboratories (MTT Agrifood Research Finland and Stockholm University, Sweden) and the results were identical. At each step of the aDNA extraction and amplification procedure, negative controls were performed. In the first extraction of our aDNA trial, a mammoth sample was used as positive control, which constitutes a suitable control because a previous study [45] has shown that it does contain mammoth DNA, it does not contain modern DNA and its sequence clearly differs from that of sheep.

\section{Mitochondrial DNA amplification of modern sheep samples}

DNA from 94 modern sheep of 10 European and Asian breeds $[3,14]$ were analysed. Additional file 2: Table S1 includes primers for the amplification of a 664-bp sequence of mtDNA [see Additional file 2: Table S1]. The same PCR reaction mix was used for these samples than for the aDNA samples except that UNG was not included. PCR conditions were as follows: $95^{\circ} \mathrm{C}$ for $15 \mathrm{~min}$ followed by 32 three-step cycles at $94^{\circ} \mathrm{C}$ for $30 \mathrm{~s}, 58^{\circ} \mathrm{C}$ for $40 \mathrm{~s}$ and $72^{\circ}$ for $1 \mathrm{~min}$ and a final step at $72^{\circ} \mathrm{C}$ for $10 \mathrm{~min} .500 \mathrm{ng}$ of template DNA were used per reaction. Y-chromosome marker data were available from a previous study [12].

\section{Sequencing of PCR products}

PCR products of modern and ancient DNA samples were purified using ExoSAP-IT enzyme (GE Healthcare Life sciences, UK). Sequencing reactions were performed using DYEnamic ET Terminator Kit (GE Healthcare Life sciences, UK). The sequencing products were purified by ethanol precipitation and separated on MegaBACE1000 ${ }^{\mathrm{TM}}$ (Amersham Biosciences, UK). Both strands of each fragment were sequenced and the same primers were used for both sequencing and fragment amplification. Sequence data were base-called with Cimarron 3.12 
basecaller using a MegaBACE Sequence analyzer v. 3.0.0111.1603 (Amersham Biosciences, UK). Sequences were analysed with Sequencher 4.68 (Gene Codes, Ann Arbor, MI).

\section{Statistical analyses}

Mitochondrial DNA sequences from 94 modern sheep [GenBank: JX484017-JX484110] and 26 ancient sheep [GenBank: JX484111-JX484137] were aligned using CLUSTALW2 [46] (penalties for gap opening, gap extension, gap distances were 10, 0.20 and 5, respectively). When statistical analyses were performed for a subset of sequences, the CLUSTALW2 alignment was carried out separately for each cohort. The size of the aligned mtDNA sequence was 523-bp. One Iron Age sample (OaPas1), for which only 297-bp of the mtDNA D-loop was sequenced, was omitted from the statistical analyses (Table 1). A corresponding CLUSTALW2 alignment was done for the Y-chromosome 130-bp sequences [JX484138- JX484140]. Alignment gaps were excluded from the statistical analyses.

The appropriate DNA substitution model to analyse our mtDNA data was the Hasegawa-Kishino-Yano model ([47]; HKY85) $+\Gamma$ supported both by FindModel [48] web server (http://www.hiv.lanl.gov/content/sequence/ findmodel/findmodel.html) and MEGA5.05 program [49] and selected on the basis of the Akaike information criterion (AIC) [48] for different models. The phylogenetic analysis of the 94 modern and 26 ancient sheep sequences and one outgroup sequence from urial sheep (Ovis vignei bochariensis [GenBank:AF039580.1]) was conducted using two approaches. MEGA5.05 was used to construct the Neighbor-joining (NJ) tree with 1000 bootstrap replicates. However, the Tamura-Nei substitution model [50] with a $\Gamma$ distribution parameter value $\alpha=0.05$ was used in the analysis because HKY is not implemented in the MEGA software and the Tamura-Nei model was supported by AIC. The maximum likelihood (ML) analysis was performed using PhyML v. 3.0 program [51] and the HKY85+ $(\operatorname{lnL}=$ $-1271.48434, \Gamma$ distribution parameter value $\alpha=0.047)$. Bootstrap support for a ML tree was calculated using 1000 bootstrap replicates and the tree was drawn with the TreeView program v. [52]. In addition, a median-joining network (with $\varepsilon=0$ to be most conservative) between the haplotypes was constructed and mismatch distribution was performed using NETWORK 4.6.0.0 [53].

The following parameters were calculated to estimate the genetic diversity of the mtDNA data in the different cohorts (i.e., in the ancient populations and modern breeds): number of haplotypes (h), number of segregating sites $(\mathrm{S})$, haplotype diversity $(\mathrm{Hd}=$ probability that two mtDNA sequences chosen randomly from the sample are different), nucleotide diversity $(\pi=$ number of nucleotide differences between randomly chosen pairs of sequences), and average number of nucleotide differences
(K) (DnaSP v.5 [54]). Theta-estimates ('theta' $\theta=\mathrm{N}_{\mathrm{e}} \mu$, where $\mathrm{N}_{\mathrm{e}}$ is the effective population size in the case of a haploid locus and $\mu$ is the overall mutation rate at the haplotype level) were computed using ARLEQUIN v. 3.5 [55]: the expected level of diversity, $\theta_{S}$, was derived from the observed number of segregating sites $S$ and $\theta_{\pi}$ from the observed mean number of pairwise nucleotide differences $\pi$. Furthermore, Tajima's D test statistic was computed using DnaSP.

We investigated the distribution of the ancient mtDNA sequences present among the 94 sequences of the modern sheep samples sequenced here and searched for shared identical sequences in the GenBank DNA database (NCBI/BLAST, http://blast.ncbi.nlm.nih.gov/ Blast.cgi). The haplotypes were determined using DnaSP [see Additional file 3: Table S2].

The ancient Y-chromosome SNP $o Y 1$ data were compared with modern data $[9,12]$ and geographic frequency distributions of $o Y 1$ alleles. The modern Y-chromosome SNP data $[9,12]$ on the frequencies of $o Y 1$ alleles are presented in Additional file 4: Table S3.

\section{Results}

\section{Radiocarbon dating}

Nineteen samples were successfully radiocarbon-dated, while for three samples, the quantity of collagen in the enamel was not sufficient for this technique (Table 1). The radiocarbon dating indicated that two samples, (OaPih1, OaKök2), were younger and one (OaUuk2) was older than inferred from the archaeological records from the same sites (Table 1). The dating results indicated that the oldest samples successfully analyzed for mtDNA were approximately 1000 years old.

\section{Success rate of aDNA analyses}

Mitochondrial DNA analysis was carried out on 36 ancient sheep samples and mtDNA amplification was successful for 27 samples, including the partial mtDNA sequence of the OaPas1 sample (Table 1). Most of these 27 samples required several amplifications per fragment in order to obtain at least three good-quality sequences from at least two PCR reactions. Excluding the samples for which no mtDNA amplification was obtained and considering all separate amplifications for the five mtDNA D-loop fragments, the amplification success rate was $46 \%$, $56 \%$ and $68 \%$ for sheep samples from the Iron Age, Medieval and Post-Medieval periods, respectively. Average amplification success rates and fragment lengths for the mtDNA D-loop sequence are summarised in [Additional file 2: Table S1]. As expected, with aDNA samples, the highest success rate was obtained when the amplified fragments of mtDNA D-loop were shortest. In addition, among the aDNA samples from different periods, those from the Post-Medieval period had the highest success 
rate, which is explained by the fact that Post-Medieval material is abundant allowing a more critical prior-selection of bones than for older materials. Reproducible sequences were obtained for seven of the 11 Medieval samples and for five (plus one partial) of the 11 Iron Age samples (Table 1).

Amplification of a 130-bp sequence of Y-chromosome 5' promoter region in the $S R Y$ gene was tested in aDNA samples that were successfully amplified for mtDNA and three contained the $S R Y$ gene sequence. As expected, among the different aDNA analyses, amplification success rate was lowest $(12 \%)$ for the fragment containing the $S R Y$ gene.

\section{Mitochondrial DNA haplotypes}

Alignment between the 94 modern and 26 ancient DNA sequences (OaPas1 containing a partial mtDNA sequence was excluded) revealed 47 SNP (46 transitions and one transversion) and three insertion-deletions [see Additional file 5: Figure S2]. When considering the alignment of the aDNA samples only, 27 transitions and no transversion were found. Fifty-six haplotypes (18 in the ancient and 46 in the modern DNA sequences) were identified among the 121 modern and ancient sheep samples (Figure 1, Tables 2 and 3). More than half of these haplotypes (30 of 56) were private to one individual and thus to one modern sheep breed or ancient sheep population indicating high variation in the analysed D-loop region.

The NJ and ML analyses gave similar phylogenetic topologies thus only the ML tree is presented in Figure 1. Two highly divergent domestic sheep lineages, ovine mtDNA haplogroups $\mathrm{A}$ and $\mathrm{B}$, were detected with relatively high statistical support. As expected, comparisons with reference sequences [GenBank: AF039577.1] and [GenBank: AF039578.1], haplogroups B and A were respectively the major and minor haplogroups. Frequencies of haplogroups A and B were $0 \%$ and $100 \%$ for the Iron Age, $28.6 \%$ and $71.4 \%$ for the Medieval and 14.3\% and $85.7 \%$ for the Post-Medieval sheep cohorts, respectively and $21.9 \%$ and $78.1 \%$ for the Finnish modern sheep breeds. In addition, the Network analysis and mismatch distribution supported the existence of these two divergent haplogroups in the modern sheep breed data presented in Figures S3 and S4 [see Additional file 6: Figures S3 and S4]. These analyses reproduced the wellestablished observations with a star-shaped pattern in the ovine mtDNA haplotype network and a smooth shape of mismatch distribution indicating a population expansion in the history of the species. Similar patterns were observed in the Medieval-Iron Age and Post-Medieval cohorts when analysed separately (results not shown).

We analysed the distribution of the 18 ancient Finnish sheep mtDNA haplotypes in the modern sheep breeds by sequencing samples of 10 Eurasian sheep breeds and by searching for shared sequences in the GenBank DNA database. The shared haplotype analysis showed that 14 of the 18 ancient haplotypes were present in the modern sheep breeds and in the GenBank DNA database (Figure 1) and [Additional file 3: Table S2]. In the modern sheep populations, frequencies of ancient haplotypes were highest in the native Finnish sheep breeds, Finnsheep (0.38) and Kainuu Grey (0.53) with six ancient haplotypes i.e. H11 in haplogroup A and H22, H32, H40, H42, H44 in haplogroup B. The two ancient haplotypes, $\mathrm{H} 05$ in haplogroup A and H32 in haplogroup B are common haplotypes while other rarer ancient haplotypes exist e.g. in contemporary native breeds from the Caucasus, Russia and Serbia [see Additional file 3: Table S2]. The four ancient haplotypes $\mathrm{H} 06, \mathrm{H} 30, \mathrm{H} 43$ and H50 were absent both in our own modern dataset and in the GenBank DNA database [see Additional file 3: Table S2].

\section{Analysis of population diversity}

The statistics summarising the level of mtDNA variation in the Finnish ancient populations and modern sheep breeds and in seven other modern Eurasian breeds are presented in Tables 2 and 3, respectively. Additional file 1: Figure S1 shows the sites from which the Finnish archaeological samples were collected and for which mtDNA was successfully amplified. The Iron Age cohort comprising only five samples and excavated at a single archaeological site on the prehistorical farm Mulli displayed the lowest values for all diversity estimates (s, h, Hd, K, and $\pi$ ). Haplotype diversity was higher in ancient sheep samples from the Medieval and Post-Medieval periods $(\mathrm{Hd}=1.0$ and 0.98 , respectively) than in any of the modern populations. The Post-Medieval samples originated from several archaeological sites, while the Medieval samples were excavated mainly in Turku. Among the modern sheep breeds analysed, Bozakh, Finnsheep and Pramenka showed the highest haplotype diversity ( $\mathrm{Hd}>0.90$; Tables 2 and 3) while Olkuska and Åland had the lowest haplotype diversity ( $\mathrm{Hd}=0.75$; Tables 2 and 3$)$. The Finnsheep samples were collected in several sheep flocks from different parts of Finland. The measures taking in account the molecular nature of the data showed highest variation in the populations and breeds in which both haplogroups $\mathrm{A}$ and $B$ were segregating. Nucleotide diversity varied among cohorts and was highest $\left(\pi=15.51 * 10^{-3}\right)$ in Pramenka sheep, originating from the Balkan region, which was one of the main dispersal routes for Near Eastern domesticated sheep entering Europe.

The diversity estimate $\theta \mathrm{s}$ is influenced by genetic bottlenecks, whereas $\theta \pi$ is relatively insensitive. Consequently, $\theta \pi-\theta \mathrm{s}$ will be negative in stable populations under an infinite-sites model of mutation-drift equilibrium and 


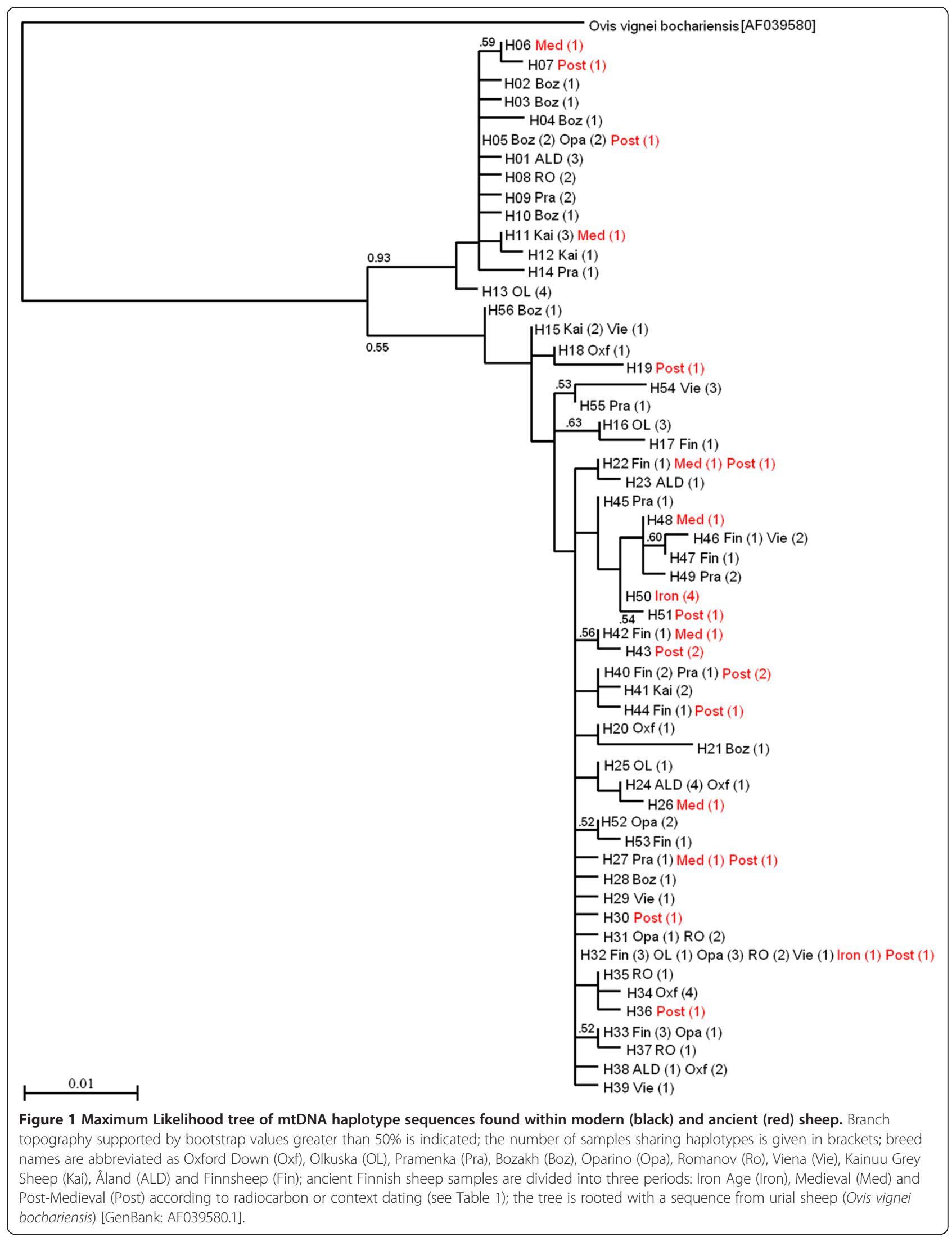


Table 2 Summary statistics of ancient Finnish sheep populations from three periods and modern Finnish sheep breeds

\begin{tabular}{|c|c|c|c|c|c|c|}
\hline \multirow[t]{2}{*}{ Statistics } & \multicolumn{3}{|c|}{ Ancient Finnish sheep } & \multicolumn{3}{|c|}{ Modern Finnish sheep breeds } \\
\hline & Post-Medieval & Medieval & Iron Age & Åland & Finnsheep & Kainuu Grey \\
\hline N & 14 & 7 & 5 & 9 & 15 & 8 \\
\hline S & 25 & 18 & 2 & 17 & 14 & 15 \\
\hline h & 12 & 7 & 2 & 4 & 10 & 4 \\
\hline $\mathrm{Hd}$ & 0.98 & 1.00 & 0.40 & 0.75 & 0.93 & 0.82 \\
\hline K & 6.13 & 7.81 & 0.80 & 7.94 & 2.61 & 8.11 \\
\hline$\pi$ & 11.72 & 14.93 & 1.53 & 15.19 & 4.99 & 15.50 \\
\hline D & -0.934 & 0.352 & -0.973 & 1.315 & -1.562 & $2.054^{*}$ \\
\hline$\theta$ s & 7.861 & 7.347 & 0.960 & 6.255 & 4.306 & 5.785 \\
\hline$\theta \pi$ & 6.396 & 8.095 & 0.800 & 7.944 & 2.743 & 8.107 \\
\hline$\theta \pi-\theta s$ & -1.465 & 0.748 & -0.16 & 1.689 & -1.563 & 2.322 \\
\hline
\end{tabular}

$\mathrm{N}$, number of sampled individuals; $\mathrm{S}$, number of segregating sites (excluding indels); h, number of haplotypes; Hd, haplotype diversity; $\mathrm{K}$, average number of differences; $\pi$, nucleotide diversity* $10^{-3} ; \mathrm{D}$, Tajima's $\mathrm{D}$ statistic value where statistically significances $\mathrm{P}<0.05$ are marked with ${ }^{*} ; \theta \mathrm{s}$, 'Theta' derived from the observed number of segregating sites $(S)$ and $\theta_{\pi}$ from the observed mean number of pairwise nucleotide differences $(\pi)$.

positive as a result of a reduction in the number of segregating sites. In our data, $\theta \pi-\theta \mathrm{s}$ estimates were negative i.e. -1.465 and -1.563 for Post Medieval and modern Finnsheep, respectively (Table 2), whereas they were positive for Åland, Kainuu Grey, Olkuska, and Pramenka sheep, and slightly positive for the Pramenka breed and the Medieval population (Tables 2 and 3). Statistically significant Tajima's D-values were positive for Kainuu Grey and Olkuska sheep, indicating a reduction of mtDNA diversity.

\section{Y-chromosome analysis}

For three of the 27 ancient sheep samples, Y-chromosome $S R Y$ sequences were amplified and were thus genetically identified as rams (Table 1) with one ram sample from the Medieval period and two from the Post-Medieval period (Table 1). All three ancient Finnish sheep had SNP G-oY1 in the $S R Y$ gene. In the modern Finnish breeds, the frequency of G-oY1 was 77\%, 57\%, and 60\% in Finnsheep, Kainuu Grey, and Åland, respectively [see Additional file 4: Table S3], indicating that SNP G-oY1 is frequent in the modern north-European breeds (Figure 2).

\section{Discussion}

We successfully analysed mtDNA and Y-chromosome diversity in ancient sheep remains from Finland and found that Finnish sheep genetic diversity has been quite constant over the last 1000 years. Our aDNA results fit well with the genetic context of the modern northEuropean domestic sheep breeds analysed either previously $[3,12]$ or in the present study. Both ovine haplogroups A and B have been present in the Finnish sheep population for at least more than 700 years and no remarkable temporal changes in their frequencies have occurred. Four of the 26 ancient mtDNA sequences

Table 3 Summary statistics of modern Polish, Russian and UK breeds

\begin{tabular}{|c|c|c|c|c|c|c|c|}
\hline \multirow[t]{2}{*}{ Statistics } & \multicolumn{7}{|c|}{ Modern sheep breeds } \\
\hline & Bozakh & Olkuska & Oparino & Oxford Down & Pramenka & Romanov & Viena \\
\hline $\mathrm{N}$ & 9 & 9 & 9 & 9 & 9 & 8 & 9 \\
\hline S & 21 & 14 & 16 & 9 & 19 & 16 & 11 \\
\hline $\mathrm{h}$ & 8 & 4 & 5 & 5 & 7 & 5 & 6 \\
\hline $\mathrm{Hd}$ & 0.97 & 0.75 & 0.86 & 0.81 & 0.94 & 0.89 & 0.89 \\
\hline K & 7.44 & 7.39 & 5.89 & 2.83 & 8.11 & 6.96 & 4.39 \\
\hline$\pi$ & 14.23 & 14.13 & 11.26 & 5.42 & 15.51 & 13.32 & 8.39 \\
\hline$D$ & -0.180 & $2.085^{*}$ & 0.002 & -0.664 & 0.786 & 0.661 & 0.397 \\
\hline$\theta s$ & 7.727 & 5.151 & 5.887 & 3.311 & 6.991 & 6.171 & 4.047 \\
\hline$\theta \pi$ & 7.667 & 7.389 & 5.889 & 2.833 & 8.333 & 6.964 & 4.389 \\
\hline$\theta \pi-\theta s$ & -0.06 & 2.238 & 0.002 & -0.478 & 1.342 & 0.793 & 0.342 \\
\hline
\end{tabular}

$\mathrm{N}$, number of individuals sampled; S, number of segregating sites (excluding indels); h, number of haplotypes; Hd, haplotype diversity; $\mathrm{K}$, average number of differences; $\pi$, nucleotide diversity ${ }^{*} 10^{-3} ; \mathrm{D}$, Tajima's $\mathrm{D}$ statistic value where statistically significances $\mathrm{P}<0.05$ are marked with *; $\theta$ s, 'Theta' derived from the observed number of segregating sites $S$ and $\theta_{\pi}$ from the observed mean number of pairwise nucleotide differences $\pi$. 


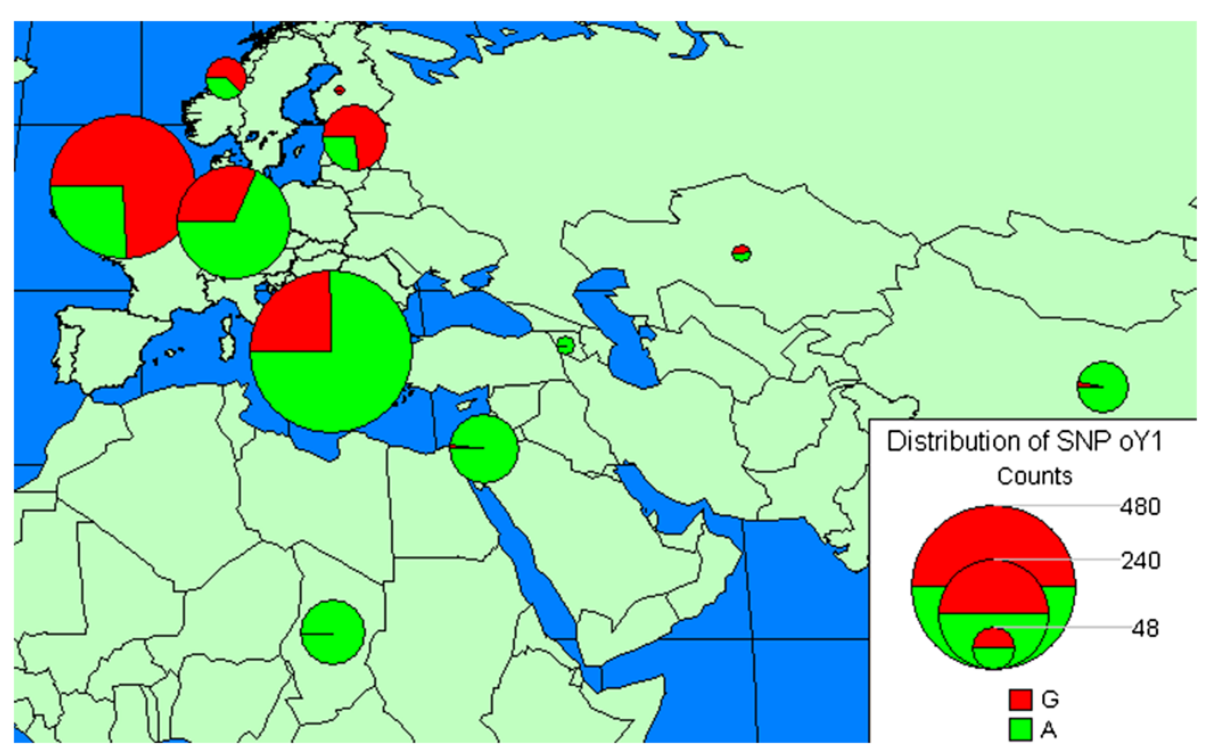

Figure 2 Distribution of Y-chromosomal SNP G- and A-oY1 in modern sheep breeds in Europe, Asia and Africa and in ancient Finnish sheep. Ancient sheep are indicated by a smaller circle over Finland at the northern most location on the map; the remaining circles on the map indicate modern sheep breeds from [9,12] listed in [Additional file 4: Table S3]; the proportions of G-oY1 and A-oY1 haplotypes are indicated in red and green, respectively; the size of the circles is proportional to sample size in each location.

obtained here were assigned to haplogroup A (the frequency in different ancient cohorts varied from 0 to 28.6\%) and 22 sequences to haplogroup B (frequency ranging between 71.4 and $100 \%)$. The respective haplogroup A and B frequencies in the present sample set of three Finnish native breeds are $21.9 \%$ and $78.1 \%$ according to our analysis and $16.7 \%$ and $83.3 \%$ according to [3]. Four of the 18 ancient mtDNA haplotypes were present in the modern Finnish native breeds and 14 in the set of 10 Eurasian breeds analysed here. The affinity between modern mtDNA haplotypes and the ancient mtDNA haplotypes not found in the modern breeds is also attested by their proximity within the phylogeny and haplotype network in Figure 1 and Figure S3 [see Additional file 6: Figure S3], respectively. According to historical written records, foreign breeding animals, which were obviously ancestors of the modern Merino sheep, were imported into Finland during the 16th, 17 th and 18th centuries $[8,56]$. However, most of the imported individuals being rams, they did not have a major impact on the mtDNA diversity in the Finnish native sheep.

In addition, results of the Y-chromosome analysis on aDNA agree well with those on DNA from modern Finnish indigenous sheep breeds. SNP G-oY1 in the 5'promoter region of the $S R Y$ gene on sheep Y-chromosome was detected in the three ancient ram samples. Since these ancient ram samples (OaNaa1, OaTor1, OaKök2, Table 1) were collected from different excavation sites and from two different time periods (Medieval and Post-Medieval), it is unlikely that they were close relatives. However, the number of available ancient ram samples is not sufficient to draw detailed conclusions on the temporal changes in the frequencies of G-oY1 and A-oY1. In the contemporary native Finnish breeds, the frequency of SNP G-oY1 ranges from 57 to 77\% [see Additional file 4: Table S3] and the frequency of SNP G-oY1 is highest in north European, British Islands and central Russian populations [12], [see Figure 2 and Additional file 4: Table S3]. SNP G$o Y 1$ is less frequent in southern and central European sheep ( $25 \%$ and $32 \%$, respectively) and very low for the remaining breeds analysed to date $(<8 \%)$ [see Figure 2 and Additional file 4: Table S3]. The presence of SNP G-oY1 in modern sheep populations often reflects introgression of English breeds [12]. However, this cannot be the case for ancient Finnish sheep. Consequently, our finding that SNP G-oY1 is present in sheep aDNA suggests that (at least in Finland) this paternal line predates the arrival of sheep in northern Europe.

Our results on radiocarbon-dating of 19 sheep remains excavated from archaeologically important sites in Finland provide essential information for Finnish archaeological research. Our research on ancient sheep material shows that previous attempts to determine the age of remains based on archeological context are fairly accurate, since only in three cases, did the dating results differ from those expected (OaPih1, OaKök2 and OaUuk2, Table 1). The oldest samples analysed here originate from the Late Iron Age from the excavation site Mulli in Raisio and from Pasvik in northern Norway. In Finnish archaeology, age determination of specimens is usually based on archaeological context. However, this 
can be misleading because, in Finland, cultural layers are thin and younger bone and other animal materials may have sunk to earlier cultural layers and thus, the dating of a single bone might differ from the general dating of a site [20]. Therefore, the dating of archaeological materials by radiocarbon methods is recommended.

Here, we investigated the genetic affinities between the ancient Finnish sheep populations and the modern sheep breeds by searching for identical matches in the GenBank DNA database with the ancient haplotype sequences. Comparison of our ancient mtDNA data with those of the contemporary breeds appears to be relatively uninformative in terms of unfolding geographic origin or origins of native sheep in Finland or the dispersal of sheep husbandry to Finland. Our results confirm that the domestic sheep populations share their origins with $O$. orientalis populations domesticated in the Near Eastern region, from where the sheep spread around the World, and that whereas haplogroup B is common in Europe, haplogroup $A$ is much rarer [1-3]. Ancient mtDNA haplotypes can be found in modern sheep breeds originating from geographically distant regions. Ancient Finnish sheep show a maternal genetic affinity to western and southern European breeds, but also to eastern European breeds. For example, haplotype $\mathrm{H} 05$ detected in the Post-Medieval sheep is also present in the two Russian (Figure 1) and the Iberian sheep breeds [see Additional file 3: Table S2] and several haplotypes of the haplogroup B detected in the Finnish ancient sheep are present in eastern, western and southern European breeds. However, four mtDNA haplotypes present in the ancient sheep samples are absent in the contemporary sheep breeds suggesting a possible loss of these haplotypes. Our results agree with a previous analysis of mtDNA D-loop polymorphisms on modern Eurasian sheep breeds in which a genetic historical influence of Russian sheep breeds in northern European sheep breeds was detected [3].

We assume that the fluctuations in mtDNA genetic diversity estimates obtained for the different cohorts (Tables 2 and 3) may be stochastic in nature as a result of genetic drift and sampling. Assuming neutrality for the mtDNA D-loop region, the high positive values for $(\theta \pi-\theta s)$ indicate a loss of genetic variability in terms of number of segregating nucleotide sites, occurring in the modern populations of Åland, Kainuu Grey, Olkuska sheep and the Serbian Pramenka population of Vlashko Vitoroga. These breeds experienced a genetic bottleneck during the 20th century and are classified as endangered sheep breeds [14]. In addition, their positive Tajima's Dvalues - statistically significantly different from zero for Kainuu Grey and Olkuska sheep - point towards an effect of a decline of population size on mtDNA diversity. In contrast, our within-population diversity estimates for Finnsheep, which is a large, major sheep population in
Finland and having descended during the 20th century from a broad founder population, do not indicate loss of mtDNA diversity in haplogroup B. However, our Finnsheep data can be considered slightly biased because we could not detect haplogroup A in our sample set [3]. When the diversity estimates of the ancient samples are compared with those of the modern breeds, values for $(\theta \pi-\theta s)$ and Tajima's D in the Medieval sheep population are similar to estimates that could be obtained for an endangered modern breed having experienced a reduction in population size. In contrast, the estimates for the Post-Medieval cohort are similar to those of a modern large sheep breed with a growing population size. However, the origin and availability of archaeological materials could explain these differences in estimates rather than demographic events that occurred in the past. The Medieval samples are mainly from one region, the Turku region, while Post-Medieval samples are from a wider geographic region, from southern, northern, western and central parts of Finland. The present Iron Age samples displaying a lower level of mtDNA diversity are from the Mulli farm from Raisio and four of the samples share the same maternal ancestry. Interestingly, it appears that the same sheep 'dam-lineage' was raised in Mulli for a long period and no new ewes were introduced into the flock.

This aDNA study focusing on sheep biodiversity in Finland shows that population genetic analysis of ancient domestic animal populations and studies investigating changes in genetic diversity across different eras are challenging. The availability of ancient materials and the success rate of ancient DNA analysis have a decisive impact on how comprehensively a sample set represents the genetic variation of ancient animal populations. In the Finnish context, survival of unburned bones from time periods prior to the Late Iron Age is infrequent due to the acid character of soils. In addition, in our study, the Medieval and Post-Medieval samples are not from the same temporal population as the samples of the modern breeds, but mainly from temporally distant generations. For example, the age difference between the oldest and youngest Medieval samples is approximately 300 years, corresponding to a time span of 100 generations. The population structures of ancient and modern cohorts are different, interfering with conclusions on temporal changes between ancient and modern populations. Moreover, the 300 years long Medieval period or Iron Age period were not socially or culturally static and our research area can be roughly divided into western, eastern and northern cultural regions with their own cultural and trade networks possibly influencing the genetic variation and structure of ancient animal populations. More ancient materials are needed to examine the archaeological questions in more detail. 


\section{Conclusions}

To date, mitochondrial DNA has been the most popular genetic marker to characterize ancient farm animal populations, to trace their ancestor and reconstitute the number of domestication events. Less is known about Ychromosome polymorphisms in ancient domestic animals partly due to challenges in Y-chromosome marker typing and partly due to the lack of polymorphic markers currently available for characterization. Here we have published one of the most comprehensive mtDNA analysis in ancient sheep populations to date and simultaneously successfully typed the Y-chromosome SNP marker $o Y 1$ in three ancient sheep samples. Our aDNA results are in agreement with the previous international studies on mtDNA and Y-chromosome diversity of domestic sheep. However, for more detailed archaeological and archaeozoological studies, such as regional historical dispersal of animal populations, and origins and relatedness of ancient animals found in a same excavation site or different sites, the resolving power of mtDNA can be too low. Our mtDNA study indicates that the same ancient and modern ovine mtDNA haplotypes can be detected in geographically distant regions. As indicated by the analysis of modern sheep breeds e.g. $[9,14]$, autosomal nuclear markers, such as microsatellites, sequence data and SNP are powerful population genetic markers. Further studies with these autosomal nuclear markers will offer an opportunity to study archaeological samples in more detail and provide more information about ancient genetic population structure than uniparentally inherited markers.

\section{Additional files}

Additional file 1: Figure S1. Title: Sample sites for ancient and modern sheep. Description: This figure presents excavation sites of ancient sheep samples included in statistical analysis.

Additional file 2: Table S1. Title: Primers used in this study. Description: This table presents primer pairs, annealing temperatures (AT), fragment length, nucleotide position of initiation of the amplification and average amplification success rates for aDNA and modern samples.

Additional file 3: Table S2. Title: Distribution of haplotypes identified in the present study and in data available from GenBank. Description: The table provides distribution of haplotypes found in this study among previously studied contemporary sheep populations [2,57-63] available in GenBank.

Additional file 4: Table S3. Title: Global distribution of $Y$ chromosomal SNPs A- oY1 and G-oY1. Description: The table provides distribution of oY1 SNPs in modern sheep breeds according to $[9,12]$. Three ancient Finnish sheep analysed in this study are added to the data.

Additional file 5: Figure S2. Title: Mitochondrial DNA haplotypes $(H)$ identified in 26 ancient and 94 modern sheep. Description: The data provided represent alignment of 26 ancient and 94 modern sheep analysed in this study. SNP positions given are relative to the reference sequence [GenBank:NC001941].

Additional file 6: Figure S3 and S4. Title: Median-joining network and mismatch distribution of the 56 mitochondrial haplotypes. Description: Figure $\mathrm{S} 3$ shows the median-joining network $(\varepsilon=0)$ with molecular relationships between 56 haplotypes which cluster into two major ovine haplogroups: haplogroup $\mathrm{A}(\mathrm{H} 01-\mathrm{H} 14$, on the left) and haplogroup B ( $\mathrm{H} 15-\mathrm{H} 56$, on the right). Figure S4 presents the mismatch distribution of 120 modern and ancient domestic sheep indicating the existence of two divergent haplogroups in the data.

\section{Competing interests}

The authors declare that they have no competing interests.

\section{Authors' contributions}

MN carried out the molecular genetic studies of ancient and modern DNA $\mathrm{MN}$ and JK performed the statistical analysis and drafted the manuscript. $A B$ and $\mathrm{JH}$ selected the ancient samples for the study and drafted the archaeological and historical parts of the manuscript. VN and TI-T participated in molecular genetic studies and the design of the laboratory methods. KL provided the education for aDNA analyses at one of the two aDNA laboratories used in the study. TI-T took part also in the statistical analyses and the manuscript writing. JK, J-PT and JS conceived the study, and participated in its design and coordination and helped to draft the manuscript. All authors read and approved the final manuscript.

\section{Acknowledgements}

This research was funded by the Academy of Finland (the project decision number 128451). We acknowledge The National Board of Antiquities, Raisio Museum Harkko, and The Museum Centre of Turku for ancient samples and Laboratory of Chronology of the Finnish Museum of Natural History, University of Helsinki for radiocarbon dating of ancient materials. Kenneth Gustavsson, Vesa-Pekka Herva, Titta Kallio-Seppä, Ville Laakso, Johanna LehtoVahtera, Mirja Miettinen, Marianna Niukkanen, Jari Näränen, Teija Oikarinen, Bjørnar Olsen, Petro Pesonen, Aki Pihlman, Hannu Poutiainen, Jaana Riikonen, Eeva-Liisa Schultz, Anna-Kaisa Salmi, and Kari Uotila are thanked for their collaboration in sampling of ancient materials. We thank Tuula-Marjatta Hamama and Anneli Virta for their excellent laboratory work.

\section{Author details}

${ }^{1}$ Biotechnology and Food Research, MTT Agrifood Research Finland, FI-31600, Jokioinen, Finland. 'Department of Archaeology, University of Turku, Fl-20014, Turku, Finland. 'Department of Zoology, Stockholm University, SE-106-91, Stockholm, Sweden. ${ }^{4}$ Archaeological Research Laboratory, Stockholm University, SE-106-91, Stockholm, Sweden. ${ }^{5}$ Current address: Molecular Systematics Laboratory, Swedish Museum of Natural History, SE-10405, Stockholm, Sweden.

Received: 17 August 2012 Accepted: 30 November 2012 Published: 22 January 2013

References

1. Zeder MA: Domestication and early agriculture in the Mediterranean Basin: Origins, diffusion, and impact. Proc Natl Acad Sci USA 2008, 105:11597-11604.

2. Meadows JRS, Cemal I, Karaca O, Gootwine E, Kijas JW: Five ovine mitochondrial lineages identified from sheep breeds of the near East. Genetics 2007, 175:1371-1379.

3. Tapio M, Marzanov N, Ozerov M, Cinkulov M, Gonzarenko G, Kiselyova T, Murawski M, Viinalass $\mathrm{H}$, Kantanen J: Sheep mitochondrial DNA variation in European, Caucasian, and Central Asian areas. Mol Biol Evol 2006, 23:1776-1783.

4. Chessa B, Pereira F, Arnaud F, Amorim A, Goyache F, Mainland I, Kao RR, Pemberton JM, Beraldi D, Stear MJ, Alberti A, Pittau M, lannuzzi L, Banabazi MH, Kazwala RR, Zhang Y, Arranz JJ, Ali BA, Wang Z, Uzun M, Dione MM, Olsaker I, Holm L, Saarma U, Ahmad S, Marzanov N, Eythorsdottir E, Holland MJ, Ajmone-Marsan P, Bruford MW, Kantanen J, Spencer TE, Palmarini M: Revealing the History of Sheep Domestication Using Retrovirus Integrations. Science 2009, 324:532-536.

5. Bläuer A, Kantanen J: Transition from hunting to animal husbandry in Southern, Western and Eastern Finland: new dated osteological evidence. J Archaeol Sci 2013, 40: 1646-1666.

6. Orrman E: Suomen keskiajan asutus. In Suomen maatalouden historia I. Perinteisen maatalouden aika esihistoriasta 1870-luvulle. Edited by Rasila V, 
Jutikkala E, Mäkelä-Alitalo A. Jyväskylä: Suomalaisen kirjallisuuden seura; 2003:67-86.

7. Luukko A: Suomen karjavarallisuus 1620-luvulla. Historiallinen aikakauskirja 1958, 56:95-116.

8. Säihke I: Varsinais-Suomen maanviljelys ja karjanhoito 1500-luvulla. Varsinais-Suomen Historia 1963, 5:7-69.

9. Kijas JW, Lenstra JA, Hayes B, Boitard S, Porto Neto LR, San Cristobal M, Servin B, McCulloch R, Whan V, Gietzen K, Paiva S, Barendse W, Ciani E, Raadsma H, McEwan J, Dalrymple B, other members of the International Sheep Genomics Consortium: Genome-wide analysis of the world's sheep breeds reveals high levels of historic mixture and strong recent selection. PLOS Biol 2012, 10:e1001258.

10. Maijala K: History, recent development and uses of Finnsheep. J Agric Sci Finland 1988, 60:449-454

11. Tapio M, Miceikiene I, Vilkki J, Kantanen J: Comparison of microsatellite and blood protein diversity in sheep: inconsistencies in fragmented breeds. Mol Ecol 2003, 12:2045-2056.

12. Meadows JR, Hanotte O, Drögemüller C, Calvo J, Godfrey R, Coltman D, Maddox JF, Marzanov N, Kantanen J, Kijas JW: Globally dispersed Y chromosomal haplotypes in wild and domestic sheep. Anim Genet 2006, 37:444-453.

13. Tapio M, Tapio I, Grislis Z, Holm LE, Jeppsson S, Kantanen J, Miceikiene I, Olsaker I, Viinalass H, Eythorsdottir E: Native breeds demonstrate high contributions to the molecular variation in northern European sheep. Mol Ecol 2005, 14:3951-3963.

14. Tapio M, Ozerov M, Tapio I, Toro MA, Marzanov N, Cinkulov M, Goncharenko G, Kiselyova T, Murawski M, Kantanen J: Microsatellite-based genetic diversity and population structure of domestic sheep in northern Eurasia. BMC Genet 2010, 11:76.

15. Li MH, Stranden I, Tiirikka T, Sevon-Aimonen ML, Kantanen J: A comparison of approaches to estimate the inbreeding coefficient and pairwise relatedness using genomic and pedigree data in a sheep population. PLoS One 2011, 6:e26256.

16. Svensson E, Götherström A: Temporal fluctuations of Y-chromosomal variation in Bos taurus. Biol Lett 2008, 4:752-754.

17. Larson G, Albarella U, Dobney K, Rowley-Conwy P, Schibler J, Tresset A, Vigne JD, Edwards CJ, Schlumbaum A, Dinu A, Bălăçsescu A, Dolman G, Tagliacozzo A, Manaseryan N, Miracle P, Van Wijngaarden-Bakker L, Masseti M, Bradley DG, Cooper A: Ancient DNA, pig domestication, and the spread of the Neolithic into Europe. Proc Natl Acad Sci USA 2007, 104:15276-15281.

18. Cai D, Han L, Zhang $X$, Zhou H, Zhu H: DNA analysis of archaeological sheep remains from China. J Archaeol Sci 2007, 34:1347-1355.

19. Cai D, Tang Z, Yu H, Han L, Ren X, Zhao X, Zhu H, Zhou H: Early history of Chinese domestic sheep indicated by ancient DNA analysis of Bronze Age individuals. J Archaeol Sci 2010, 38:896-902.

20. Tourunen A: Burnt, fragmented and mixed: Identification and interpretation of domestic animal bones in Finnish burnt bone assemblages. Fennoscandia Archaeologica 2011, 28:57-69.

21. Schultz EL: Mikkeli Moisio Latokallio/Moisionpelto ja Mikkelin MIk Kyyhkylä/ Porrassalmenpelto: Finnish National Board of Antiquities, Department of Archaeology; 1993

22. Vuorinen J: Rakennukset ja rakentajat Raision Ihalassa rautakauden Iopulla ja varhaisella keskiajalla, Volume 281: University of Turku, Annales Universitatis Turkuensis C; 2009. PhD thesis.

23. Poutiainen $\mathrm{H}$ : Sysmä Ihananiemi. Arkeologinen koekaivaus rautakautisella muinaisjäännösalueella: Lahti City Museum and Päijät-Häme Provincial Museum; 2000.

24. Riikonen J: Gravundersökningar. Koroinen eläväksi - Korois till liv. Proccedings of the Korois-seminarium: 7-8 April 2001. Åbo landskapsmuseum rapporter 2003, 19:21-24

25. Lehtosalo-Hilander PL: Luistari/l. The Graves. Helsinki: Suomen muinaismuistoyhdistyksen aikakauskirja; 1982.

26. Tupala U: Eläinuhreja vai teurasjätettä - Euran Luistarin rautakautisen ruumiskalmiston eläinluumateriaalin lähdekriittistä tarkastelua: University of Turku, Department of Archaeology; 1999. MA thesis.

27. Hedman SD, Olsen B: Transition and order. A study of Sámi rectangular hearths in Pasvik, Arctic Norway. Fennoscandia Archaeologica 2009, 26:3-23.

28. Uotila K: Hautausmaan kaivaukset vuosina 2005-2007. In Naantalin luostarin rannassa. Stranden vid Nådendals kloster. Edited by Uotila K. Eura: Kåkenhus - kirjat nro 3; 2011:183-200.
29. Alenius T, Laakso V: Palaeoecology and archaeology of the village of Uukuniemi, Eastern Finland. Acta Borealia 2006, 23:145-165.

30. Pihlman A: Åbo Akademin päärakennuksen tontin kaivaukset osana Turun kaupunkiarkeologiaa. In Kaupunkia pintaa syvemmältä - Arkeologisia näkökulmia Turun historiaan. Volume IX. Edited by Seppänen L. Turku: Archaeologia Medii Aevi Finlandiae; 2003:69-76.

31. Sartes M: Rettigin palatsin tontista tuli Aboa Vetus-museo. In Kaupunkia pintaa syvemmältä - Arkeologisia näkökulmia Turun historiaan. Edited by Seppänen L. Turku: Archaeologia Medii Aevi Finlandiae; 2003:77-86.

32. Gustavsson K: Franciskanerkloster på Kökar. Nytt ljus över medeltiden i Skärgårdshavet. Historisk Tidskrift för Finland 1994, 79:494-518.

33. Niukkanen M: Sirpaleita Suurvalta-ajan Helsingistä. Hämeenlinna: Karisto Oy; 2002.

34. Kallio T: Oulu, Oulun kadut: Oikokatu, Kajaaninkatu, Torikatu, Ojakatu, Saaristonkatu, Franzenin puisto. Katutöiden arkeologinen valvonta: Finnish National Board of Antiquities, Department of Monuments and Sites; 2005.

35. Kallio-Seppä T: Oulu, Lyseo 1/11/1. Kaupunkiarkeologinen koekaivaus 27.4.21.5.2007: Finnish National Board of Antiquities, Department of Monuments and Sites; 2007.

36. Herva VP: Oulu Pikisaari, historiallisen ajan kaivaustutkimus 15.-26.5.2006. University of Oulu: Archaeological laboratory; 2006.

37. Oikarinen T: Pietarsaari, 2/2/7-10, Lassfolkin kortteli (PSL-08). Kaupunkiarkeologinen pelastuskaivaus 19.5.-8.8.2008: Finnish National Board of Antiquities, Department of Monuments and Sites; 2009.

38. Herva VP: Kaupunkiarkeologinen pelastuskaivaus, Tornion Keskikatu 29-35: University of Oulu, Archaeological laboratory; 2002.

39. Miettinen M: Pihtiputaan Hämeensaari. Uutta tietoa Keski-Suomen historiasta. In Lapinraunioita ja Hiidenkiukaita. Volume 3. Edited by Purhonen P. Museovirasto: Arkeologian osasto; 1993:52-64.

40. Rasali DP, Shrestha JNB, Crow GH: Development of composite sheep breeds in the world: A review. Can J Anim Sci 2006, 86:1-24.

41. Yang DY, Eng B, Waye JS, Dudar JC, Saunders SR: Technical note: improved DNA extraction from ancient bones using silica-based spin columns. Am J Phys Anthropol 1998, 105:539-543.

42. Rozen S, Skaletsky H: Primer3 on the WWW for general users and for biologist programmers. In Bioinformatics Methods and Protocols: Methods in Molecular Biology. Volume 132. Edited by Krawetz S, Misener S. Totowa: Humana Press; 2000:365-386.

43. Cooper A, Poinar HN: Ancient DNA: do it right or not at all. Science 2000, 289:1139.

44. Rizzi E, Lari M, Gigli E, De Bellis G, Caramelli D: Ancient DNA studies: new perspectives on old samples. Genet Sel Evol 2012, 44:21.

45. Nyström V, Dalen L, Vartanyan S, Liden K, Ryman N, Angerbjörn A: Temporal genetic change in the last remaining population of woolly mammoth. Proc R Soc B 2010, 277:2331-2337.

46. Chenna R, Sugawara H, Koike T, Lopez R, Gibson TJ, Higgins DG, Thompson JD: Multiple sequence alignment with the Clustal series of programs. Nucleic Acids Res 2003, 31:3497-3500.

47. Hasegawa M, Kishino K, Yano T: Dating the human-ape splitting by a molecular clock of mitochondrial DNA. J Mol Evol 1985, 22:160-174.

48. Posada D, Crandall KA: MODELTEST: testing the model of DNA substitution. Bioinformatics 1998, 14:817-818.

49. Tamura K, Dudley J, Nei M, Kumar S: MEGA4: Molecular evolutionary genetics analysis (MEGA) software version 4.0. Mol Biol 2007, 24:1596-1599.

50. Tamura K, Nei M: Estimation of the number of nucleotide substitutions in the control region of mitochondrial DNA in humans and chimpanzees. Mol Biol Evol 1993, 10:512-526.

51. Guindon S, Gascuel O: A simple, fast, and accurate algorithm to estimate large phylogenies by maximum likelihood. Syst Biol 2003, 52:696-704.

52. Page RD: TreeView: an application to display phylogenetic trees on personal computers. Comput Appl Biosci 1996, 12:357-358.

53. Bandelt HJ, Forster $P$, Röhl A: Median-joining networks for inferring intraspecific phylogenies. Mol Biol Evol 1999, 16:37-48

54. Librado P, Rozas J: DnaSP v5: a software for comprehensive analysis of DNA polymorphism data. Bioinformatics 2009, 25:1451-1452.

55. Excoffier L, Lischer HE: Arlequin suite ver 3.5: a new series of programs to perform population genetics analyses under Linux and Windows. Mol Ecol Resour 2010, 10:564-567.

56. Niemelä J: Lääninlampureista maaseutukeskuksiin. Maaseutukeskusten ja niiden edeltäjien maatalousneuvonta 1700-Iuvulta 1990-Iuvulle. Tampere: Suomen Historiallinen Seura; 1996. 
57. Wang X, Chen H, Lei CZ: Genetic diversity and phylogenetic analysis of the mtDNA D-loop region in tibetan sheep. Asian-Aust J Anim Sci 2007, 20:313-315

58. Wang X, Ma YH, Chen H, Guan WJ: Genetic and phylogenetic studies of Chinese native sheep breeds (Ovis aries) based on mtDNA D-loop sequences. Small Ruminant Res 2007, 72:232-236.

59. Guo J, Du L, Ma YH, Guan WJ, Li HB, Zhao QJ, Li X, Rao SQ: A novel maternal lineage revealed in sheep (Ovis aries). Anim Genet 2005, 36:331-336.

60. Hiendleder S, Kaupe B, Wassmuth R, Janke A: Molecular analysis of wild and domestic sheep questions current nomenclature and provides evidence for domestication from two different subspecies. Proc Biol Sci 2002, 269:893-904.

61. Pedrosa S, Arranz JJ, Brito N, Molina A, San Primitivo F, Bayon Y: Mitochondrial diversity and the origin of Iberian sheep. Genet Sel Evol 2007, 39:91-103.

62. Pedrosa S, Uzun M, Arranz JJ, Gutierrez-Gil B, San Primitivo F, Bayon Y: Evidence of three maternal lineages in Near Eastern sheep supporting multiple domestication events. Proc R SOC B 2005, 272:2211-2217.

63. Pereira F, Davis SJ, Pereira L, McEvoy B, Bradley DG, Amorim A: Genetic signatures of a Mediterranean influence in Iberian Peninsula sheep husbandry. Mol Biol Evol 2006, 23:1420-1426.

doi:10.1186/1297-9686-45-2

Cite this article as: Niemi et al:: Mitochondrial DNA and Y-chromosomal diversity in ancient populations of domestic sheep (Ovis aries) in

Finland: comparison with contemporary sheep breeds. Genetics Selection Evolution 2013 45:2.

\section{Submit your next manuscript to BioMed Central and take full advantage of:}

- Convenient online submission

- Thorough peer review

- No space constraints or color figure charges

- Immediate publication on acceptance

- Inclusion in PubMed, CAS, Scopus and Google Scholar

- Research which is freely available for redistribution 